\title{
ANALISIS PENGARUH KUALITAS WEBSITE CROWDFUNDING KITABISA.COM TERHADAP PENGGALANGAN DANA COVID-19 MENGGUNAKAN METODE E-S-QUAL DAN WEBQUAL 4.0
}

\author{
Siti Khofifah ${ }^{1}$, Theresiawati ${ }^{2}$, I Wayan Widi $\mathbf{P}^{3}$ \\ Universitas Pembangunan Nasional Veteran Jakarta ${ }^{1,2,3,4}$ \\ Jalan RS. Fatmawati, Jakarta Selatan \\ Sur-el : sitikhofifah@upnvj.ac.id ${ }^{1}$, theresiawati@upnvj.ac.id ${ }^{2}$, wayan.widi@upnvj.ac.id ${ }^{4}$
}

\begin{abstract}
Kitabisa.com is one of Indonesia's online crowdfunders that has a big share in fundraising and donations by utilizing websites and mobile applications for individuals, organizations, associations, or companies for various donation purposes, whether social, personal, creative and others. The level of wesite quality become a factor that must be considered in a website crowdfunding. Therefore we need a website analysis using the E-S-Qual method and Webqual 4.0 method. Data collection technique used a questionnaire and obtained 203 respondents. Data processing in this study using Smartpls 3.0. The test results of the seven hypotheses, there were 3 rejected hypotheses, namely privacy, compensation, and contact. The results of his research that the level of quality of the website has a significant effect on user satisfaction in making donations to Kitabisa.com. This is evident from the rsquare value of 0.574. These results indicate that $57.4 \%$ user satisfaction level of website quality significantly affects user satisfaction in making donations on Kitabisa.com, and recommendations for improving the quality of the Kitabisa.com website
\end{abstract}

Keywords: Webqual 4.0, E-S Qual, Crowdfunding, Website quality

\begin{abstract}
Abstrak : Kitabisa.com merupakan salah satu online crowdfunding Indonesia yang memiliki andil besar dalam penggalangan dana dan donasi dengan memanfaatkan website dan aplikasi mobile bagi perorangan, organisasi, paguyuban, ataupun perusahaan untuk bermacam-macam tujuan donasi baik sosial, pribadi, kreatif dan lainnya. Tingkat Kualitas sebuah website menjadi sebuah faktor yang harus diperhatikan dalam sebuah website crowdfunding. Oleh karena itu diperlukannya analisis pengukuran kualitas website dengan memakai metode E-S-Qual dan Webqual 4.0. Teknik pengumpulan datanya memakai kuesioner dan diperoleh 203 responden. Pengolahan data pada penelitian ini menggunakan Smartpls 3.0. Hasil pengujian dari tujuh hipotesis terdapat 3 hipotesis yang tertolak, yaitu privacy, compensation, dan contact. Hasil penelitiannya memperlihatkan tingkat kualitas website secara signifikan berpangaruh pada kepuasan pengguna dalam melakukan donasi di Kitabisa.com hal ini terbukti dari nilai r-square 0,574. Hasil ini menunjukkan bahwa 57,4\% Kepuasan pengguna memperlihatkan tingkat kualitas website secara signifikan berpangaruh pada kepuasan pengguna dalam melakukan donasi di Kitabisa.com, dan rekomendasi untuk memingkatkan tingkat kualitas website Kitabisa.com.
\end{abstract}

Kata kunci: Webqual 4.0, E-S Qual, Crowdfunding, Website quality

\section{PENDAHULUAN}

Pemberlakuan Pembatasan Sosial Berskala Besar (PSBB) dan Pemberlakuan Pembatasan Kegiatan Masyarakat (PPKM) di sejumlah wilayah Indonesia menjadikan terbatasnya aktivitas masyarakat. Hal ini menjadi salah satu faktor penurunan perekonomian, melemahnya nilai tukar rupiah dan bertambahnya jumlah pengangguran di Indonesia. Berdasarkan data yang dikeluarkan oleh Kemenkeu Indonesia 
(2020), pandemi corona ini menjadikan 1,5 juta pegawai di pemutusan hubungan kerja (PHK) dan dirumahkan, 1,2 juta pegawai berasal dari sektor formal dan 265 ribu dari sektor informal. Tidak hanya terjadi PHK secara besar - besaran, Pemerintah juga mengalami kendala dalam penanganan pandemi diantaranya kekurangan alat - alat kesehatan untuk menangani pasien Covid. Untuk membantu Pemerintah dalam menangani pandemi dan penurunan perekonomian agar tidak berkepanjangan, masyarakat bergotong-royong dengan cara menghimpun dana untuk melawan pandemi covid 19 melalui website Kitabisa.com online crowdfunding Indonesia. Proses crowdfunding terjadi dimana sekelompok orang (berjumlah banyak) secara finansial memberikan sejumlah uang sebagai sumbangan atau turut berpartisipasi mendukung pendanaan suatu proyek [1]. Pelaksanaan penggalangan dana dilakukan oleh sejumlah pihak yang menyandang dana dengan minat yang sejalan secara daring melalui website.

Dalam suatu website crowdfunding, kualitas website menjadi elemen terpenting dikarenakan keberhasilan website diukur dengan melakukan analisis pengukuran kualitas website berdasarkan persepsi pengguna dan akan berpengaruh besar bagi konsumen dalam memilih penyedia jasa serta layanan jasa [2][3]. Kualitas website akan berpengaruh secara signifikan terhadap kepuasan pengguna dan membuat keputusan untuk melakukan penggalangan dana atau keputusan untuk memberikan donasi melalui kitabisa.com, dikarenakan pengguna website kitabisa.com saat akan bertransaksi atau memberikan donasi, langkah awalnya menyetujui persyaratan dan ketentuan yang berlaku serta mempercayakan penggalangan dana pada Kitabisa.com.

Angka pemakaian kitabisa.com pada pandemic corona ini tergolong tinggi, berdasarkan traffic overview dari situs similarweb di bulan Maret 2020 pada gambar 1 website kitabisa.com mengalami peningkatan total pengunjung sebesar $65,65 \%$ ataupun sekitar 3,48 juta pengunjung. Bahkan menempati urutan ke 2518 dunia pada kategori media dan berita.

\section{Traffic Overview}
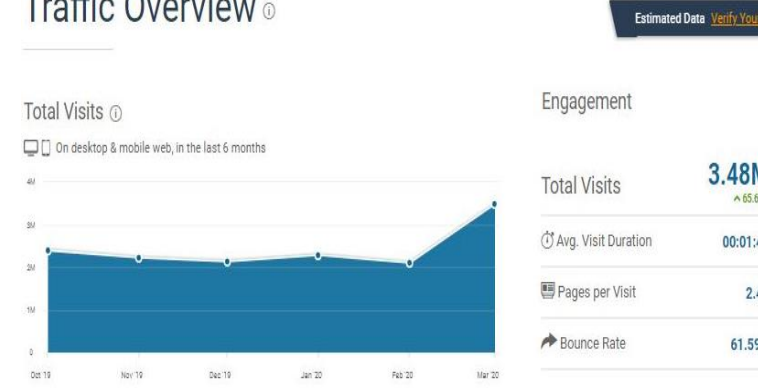

Engagement

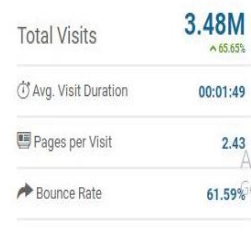

\section{Gambar 1. Traffic Overview Kitabisa.com}

Jumlah pengunjung website kitabisa.com tidak bisa dijadikan jaminan kualitas website online crowdfunding. Diperlukan adanya analisis tingkat kualitas website Kitabisa.com untuk mengetahui kualitas website crowdfunding berdasarkan persepsi pengguna serta dampaknya terhadap keputusan pengguna untuk berdonasi pada website crowdfunding Kitabisa.com. Metode yang digunakan untuk melakukan analisis kualitas website kitabisa.com yaitu metode E-S-Qual dan Webqual 4.0. Sehingga tingkat kualitas website Kitabisa.com dapat meningkat serta penggalangan dana penanganan pandemi covid 19 dapat terlaksana dengan baik.

Berdasarkan hal tersebut diatas, pertanyaan penelitian yang akan dijawab dalam 
penelitian ini adalah "Bagaimana kualitas website dan pengaruh kualitas website dalam keputusan pengguna berdonasi pada situs website Kitabisa.com berdasarkan perspektif pengguna menggunakan metode E-S-Qual dan Webqual 4.0?".

\section{METODOLOGI PENELITIAN}

Metodologi penelitian yang digunakan dalam penelitian ini dimulai dari melakukan identifikasi dan merumuskan permasalahan, studi literatur, menentukan metode penelitian, melakukan pembuatan kuesioner serta menentukan responden yang akan di teliti yaitu pengguna website Kitabisa.com. Setelah dilakukan pengumpulan data melalui kuesioner yang dilakukan secara daring kemudian dilakukan pengujian hasil kuesioner meliputi uji validitas dan realibilitas. Melakukan analisis data, penentuan faktor yang perlu ditingkatkan serta rekomendasi perbaikan website Kitabisa.com.

Pendekatan penelitian yang digunakan merupakan pendekatan kuantitatif dengan menggunakan dimensi metode e-s-qual dan webqual 4.0 untuk dapat menjelaskan keterhubungan antara variabel-variabel yang diteliti dengan mengumpulkan data-data numerik dari sampel penelitian yang kemudian dianalisis dengan menggunakan metode statistik tertentu. Pengumpulan data dengan metode kuesioner online (secara tidak langsung) yang dibuat dengan Google form. Penyebaran kuesioner online ini dilakukan melalui social media (Twitter dan Instagram) yang biasanya disebar di kolom komentar postingan mengeni covid-19 maupun bantuan terhadap covid-19, dikarenakan karakteristik dari responden yaitu pernah berdonasi mengenai covid-19 pada platform kitabisa.com. Penyebaran kuesioner online ini menggunakan online chatting (Whatsapp dan Line) sebagai media penyebaran kuesioner. Penyebaran kuesioner ini dilakukan pada tanggal 6 Desember 2020 - 18 Desember 2020. Populasi dalam penelitian ini adalah pengguna website Kitabisa.com sebanyak 236 reponden namun hanya ada 203 responden yang bisa diteruskan pada tahapan selanjutnya. Data yang tidak valid merupakan responden yang tidak pernah berdonasi mengenai covid-19 pada platform kitabisa.com. Secara persentasi sebanyak $86 \%$ dari jumlah responden yang datanya dapat dilanjutkan ke tahap berikutnya. Dan ada $14 \%$ yaitu 33 responden yang datanya dihapus dan tidak bisa diteruskan pada tahapan selanjutnya. Metode yang digunakan untuk melakukan pengolahan data yaitu menggunakan Google sheet dan di export kedalam Microsoft Excel kemudian diolah menggunakan SmartPLS.

\section{HASIL DAN PEMBAHASAN}

\section{a. Uji Kuesioner}

Sebelum kuesioner disebarkan kepada pengguna website kitabisa.com terlebih dahulu dilakukan uji kelayakan kuesioner yaitu uji validitas dan uji realibilitas dengan menggunakan Microsoft Excel dan SmartPLS3. Pengujian kuesioner dilakukan terhadapt 30 responden. Konstruk kuesioner (dimensi webqual dan e-s-qual) berjumlah 8 dengan total 
36 pernyataan. Berikut tabel konstruk dan pernyataan yang digunakan terlihat pada Tabel 1 kuesioner webqual, Tabel 2 kuesioner E-S-Qual dan Tabel 3 User Satisfaction.

Tabel 1. Kuesioner Webqual

\begin{tabular}{ll}
\hline Kode & \multicolumn{1}{c}{ Pernyataan } \\
\hline U1 & $\begin{array}{l}\text { kitabisa.com memberikan pengalaman } \\
\text { yang positif untuk pengguna }\end{array}$ \\
U2 & $\begin{array}{l}\text { Tampilan website kitabisa.com menarik } \\
\text { Tampilan kitabisa.com sesuai dengan } \\
\text { tipenya (website crowdfunding) }\end{array}$ \\
U4 & $\begin{array}{l}\text { Navigasi dan petujuk yang jelas diberikan } \\
\text { oleh situs kitabisa.com }\end{array}$ \\
U5 & $\begin{array}{l}\text { Kitabisa.com memberikan interaksi yang } \\
\text { jelas dan mudah dimengerti }\end{array}$ \\
U6 & $\begin{array}{l}\text { Kitabisa.com mudah untuk dioprasikan } \\
\text { dan dipelajari }\end{array}$ \\
IQ1 & $\begin{array}{l}\text { Kitabisa.com menyediakan informasi yang } \\
\text { akurat }\end{array}$ \\
Kitabisa.com menampilkan informasi yang \\
IE
\end{tabular}

Tabel 2. Kuesioner ES-Qual

\begin{tabular}{|c|c|}
\hline Kode & Pernyataan \\
\hline FUL1 & $\begin{array}{l}\text { Kitabisa.com memberikan informasi } \\
\text { yang dibutuhkan kepada } \\
\text { tentang berdongasi Covid-19 }\end{array}$ \\
\hline FUL2 & $\begin{array}{l}\text { Informasi donasi yang disajikan pada } \\
\text { website Kitabisa.com bersifat jujur }\end{array}$ \\
\hline FUL3 & $\begin{array}{l}\text { Kitabisa.com menjaga aktivitas donasi } \\
\text { yang aman dan nyaman }\end{array}$ \\
\hline PRI1 & $\begin{array}{l}\text { Kitabisa.com melindungi data personal } \\
\text { pengguna }\end{array}$ \\
\hline PRI2 & $\begin{array}{l}\text { Kitabisa.com aman dari serangan } \\
\text { keamanan informasi }\end{array}$ \\
\hline PRI3 & $\begin{array}{l}\text { Website kitabisa.com memberikan rasa } \\
\text { percaya kepada pengguna saat berdonasi }\end{array}$ \\
\hline PRI4 & $\begin{array}{l}\text { Website kitabisa.com memberikan rasa } \\
\text { aman kepada pengguna saat berdonasi }\end{array}$ \\
\hline PRI5 & $\begin{array}{l}\text { Pengguna yakin informasinya akan } \\
\text { terlindungi saat berdonasi } \\
\text { kitabisa.com }\end{array}$ \\
\hline COM1 & $\begin{array}{l}\text { Pengguna dapat melakukan proses re- } \\
\text { fund dana saat terjadi masalah saat } \\
\text { berdonasi }\end{array}$ \\
\hline COM2 & $\begin{array}{l}\text { Kitabisa.com menyediakan customer } \\
\text { service yang responsible }\end{array}$ \\
\hline CON1 & $\begin{array}{l}\text { Kitabisa.com menyediakan call center } \\
\text { dan live chat yang dapat mengatasi } \\
\text { masalah pengguna }\end{array}$ \\
\hline CON2 & $\begin{array}{l}\text { Kitabisa.com memberikan layanan } \\
\text { customer service yang dapat diakses } 24 \\
\text { jam }\end{array}$ \\
\hline CON3 & $\begin{array}{l}\text { Pengguna kitabisa.com } \\
\text { menemukan dan mengakses customer } \\
\text { service }\end{array}$ \\
\hline
\end{tabular}

Tabel 3. Kuesioner User Satisfaction

\begin{tabular}{|c|c|}
\hline Kode & Pernyataan \\
\hline US1 & $\begin{array}{l}\text { Saya suka dengan tampilan website } \\
\text { Kitabisa.com }\end{array}$ \\
\hline US2 & $\begin{array}{l}\text { Saya suka dengan layanan website } \\
\text { Kitabisa.com }\end{array}$ \\
\hline US3 & Akses pada website Kitabisa.com cepat \\
\hline US4 & $\begin{array}{l}\text { Informasi yang didapatkan dari website } \\
\text { Kitabisa.com bermanfaat bagi saya }\end{array}$ \\
\hline US5 & $\begin{array}{l}\text { Website Kitabisa.com dapat diakses } \\
\text { menggunakan gadget apapun }\end{array}$ \\
\hline US6 & $\begin{array}{l}\text { Setiap hari saya mengakses website } \\
\text { kitabisa.com }\end{array}$ \\
\hline
\end{tabular}


Dalam pengujian ini nilai outer loading pada tiap indikator harus diatas 0,6 - 0,7 yang berarti indikator tersebut valid[4]. Pengujian ini dinamakan standardized loading factor yang merupakan kolerasi antara tiap indikator yang dilihat dari nilai outer loading tiap indikator yang ada dalam kuesioner.

Tabel 4. Hasil Loading Factor

\begin{tabular}{|c|c|c|c|c|c|c|c|c|}
\hline & COM & $\mathrm{CON}$ & FUL & $I Q$ & PRI & SIQ & $\boldsymbol{U}$ & $U S$ \\
\hline COM1 & 0.837 & & & & & & & \\
\hline COM2 & 0.649 & & & & & & & \\
\hline CON1 & & 0.949 & & & & & & \\
\hline CON2 & & 0.906 & & & & & & \\
\hline CON3 & & 0.928 & & & & & & \\
\hline FUL1 & & & 0.878 & & & & & \\
\hline FUL2 & & & 0.912 & & & & & \\
\hline FUL3 & & & 0.87 & & & & & \\
\hline IQ1 & & & & 0.728 & & & & \\
\hline IQ2 & & & & 0.728 & & & & \\
\hline IQ3 & & & & 0.749 & & & & \\
\hline IQ4 & & & & 0.757 & & & & \\
\hline IQ5 & & & & 0.82 & & & & \\
\hline IQ6 & & & & 0.766 & & & & \\
\hline IQ7 & & & & 0.675 & & & & \\
\hline PRI1 & & & & & 0.829 & & & \\
\hline PRI2 & & & & & 0.751 & & & \\
\hline PRI3 & & & & & 0.714 & & & \\
\hline PRI4 & & & & & 0.767 & & & \\
\hline PRI5 & & & & & 0.847 & & & \\
\hline SIQ1 & & & & & & 0.803 & & \\
\hline SIQ2 & & & & & & 0.844 & & \\
\hline SIQ3 & & & & & & 0.926 & & \\
\hline SIQ4 & & & & & & 0.847 & & \\
\hline $\mathrm{U} 1$ & & & & & & & 0.554 & \\
\hline $\mathrm{U} 2$ & & & & & & & 0.594 & \\
\hline U3 & & & & & & & 0.814 & \\
\hline $\mathrm{U} 4$ & & & & & & & 0.829 & \\
\hline U5 & & & & & & & 0.813 & \\
\hline U6 & & & & & & & 0.841 & \\
\hline US1 & & & & & & & & 0.603 \\
\hline US2 & & & & & & & & 0.779 \\
\hline US3 & & & & & & & & 0.716 \\
\hline US4 & & & & & & & & 0.868 \\
\hline US5 & & & & & & & & 0.73 \\
\hline US6 & & & & & & & & 0.65 \\
\hline
\end{tabular}


Berdasarkan hasil loading factor pada tabel 4 terdapat 2 indikator yang dihapus karena hasil outer loading dibawah 0,6 yaitu variabel usability; U1 (kitabisa.com memberikan pengalaman yang positif untuk pengguna) dan U2 (Tampilan website kitabisa.com menarik). Selanjutnya dilakukan uji konsistensi reliabilitas internal dengan melihat nilai reliabilitas komposit (Composite reliability). Jika nilai reliabilitas komposit sama dengan ataupun > 0,70 dikatakan baik untuk penelitian [5].

Tabel 5 Hasil Composite Reliability

\begin{tabular}{lc}
\hline \multicolumn{2}{c}{$\begin{array}{c}\text { Composite } \\
\text { Reliability }\end{array}$} \\
\hline COM & 0.715 \\
CON & 0.949 \\
FUL & 0.917 \\
IQ & 0.898 \\
PRI & 0.888 \\
SIQ & 0.916 \\
U & 0.883 \\
US & 0.871 \\
\hline
\end{tabular}

Hasil pada tahap uji konsistensi reliabilitas yang disajikan pada tabel 5 menunjukan reliabilitas komposit memiliki nilai diatas 0,7 pada setiap variable sehingga model penelitian memiliki reliabilitas yang baik. Selanjutnya Data pada pengujian individual item reliability diperoleh dari 203 responden yang disebarkan melalui google form. Hasil dari Uji Individual Item Reliability bisa dicermati dalam tabel 6 .

Tabel 6 Loading Factor

\begin{tabular}{cccc}
\hline Variabel & Indikator & $\begin{array}{c}\text { Loading } \\
\text { Factor }\end{array}$ & $\begin{array}{c}\text { Keteranga } \\
\boldsymbol{n}\end{array}$ \\
\hline \multirow{3}{*}{ Fulfillment } & FUL1 & 0,851 & Valid \\
& FUL2 & 0,759 & Valid \\
Privacy & FUL3 & 0,824 & Valid \\
& PRI1 & 0,723 & Valid
\end{tabular}

\begin{tabular}{|c|c|c|c|}
\hline Variabel & Indikator & $\begin{array}{c}\text { Loading } \\
\text { Factor }\end{array}$ & $\begin{array}{c}\text { Keteranga } \\
n\end{array}$ \\
\hline \multirow{7}{*}{$\begin{array}{l}\text { Compensati } \\
\text { on }\end{array}$} & PRI2 & 0,809 & Valid \\
\hline & PRI3 & 0,838 & Valid \\
\hline & PRI4 & 0,789 & Valid \\
\hline & PRI5 & 0,846 & Valid \\
\hline & COM1 & 0,869 & Valid \\
\hline & COM2 & 0,869 & Valid \\
\hline & CON1 & 0,889 & Valid \\
\hline \multirow[t]{3}{*}{ Contact } & CON2 & 0,925 & Valid \\
\hline & CON3 & 0,919 & Valid \\
\hline & U3 & 0,858 & Valid \\
\hline \multirow{3}{*}{ Usability } & $\mathrm{U} 4$ & 0,857 & Valid \\
\hline & U5 & 0,858 & Valid \\
\hline & U6 & 0,804 & Valid \\
\hline \multirow{7}{*}{$\begin{array}{c}\text { Information } \\
\text { Quality }\end{array}$} & IQ1 & 0,761 & Valid \\
\hline & IQ2 & 0,797 & Valid \\
\hline & IQ3 & 0,788 & Valid \\
\hline & IQ4 & 0,701 & Valid \\
\hline & IQ5 & 0,789 & Valid \\
\hline & IQ6 & 0,811 & Valid \\
\hline & IQ7 & 0,766 & Valid \\
\hline \multirow{4}{*}{$\begin{array}{c}\text { Service } \\
\text { Interaction } \\
\text { Quality }\end{array}$} & SIQ1 & 0,795 & Valid \\
\hline & SIQ2 & 0,837 & Valid \\
\hline & SIQ3 & 0,812 & Valid \\
\hline & SIQ4 & 0,833 & Valid \\
\hline \multirow{6}{*}{$\begin{array}{c}\text { User } \\
\text { Satisfaction }\end{array}$} & US1 & 0,142 & Tidak Valid \\
\hline & US2 & 0,810 & Valid \\
\hline & US3 & 0,780 & Valid \\
\hline & US4 & 0,879 & Valid \\
\hline & US5 & 0,778 & Valid \\
\hline & US6 & 0,145 & Tidak Valid \\
\hline
\end{tabular}

Berdasarkan data pada tabel 6, variabel user satisfaction yaitu indikator US1 dan US6 memiliki nilai loading factor $<0,6$ jadi indikatornya tidak dipakai. Sehingga indicator US1 dan US6 di hapus dan tidak diikutkan dalam perhitungan selanjutnya. Setelah dihapusnya 2 (dua) indikator dari User Satisfaction yaitu US1 (Kitabisa.com memberikan pengalaman yang positif untuk pengguna), US6 (Setiap hari saya mengakses website kitabisa.com) dan dilakukan uji 
validitas, hasil loading factor masing-masing indikatornya mempunyai nilai > 0,6 maka semua indikatornya dikatakan valid dari model.

Selanjutnya dilakukan uji Uji validitas komposit merupakan pengukuran ketepatan instrument pengukuran pada penelitian. Dalam pengujian ini menghasilkan nilai reliabilitas komposit (Composite reliability) dan Cronbach Alpha. Bahwa nilai reliabilitas komposit sama dengan ataupun > 0,70 maka dinyatakan baik untuk penelitian [5]. Nilai Cronbach alpha > 0,60 artinya memiliki variabel yang reliabel dan valid[6].

Tabel 7. Uji Validitas

\begin{tabular}{lcc}
\hline \multicolumn{1}{c}{ Variabel } & $\begin{array}{c}\text { composite } \\
\text { reliability }\end{array}$ & $\begin{array}{c}\text { cronbach's } \\
\text { alpha's }\end{array}$ \\
\hline Compensation & 0,861 & 0,676 \\
Contact & 0,936 & 0,898 \\
Fulfillment & 0,853 & 0,743 \\
Information Quality & 0,913 & 0,888 \\
Privacy & 0,900 & 0,862 \\
Service Interaction & 0,891 & 0,837 \\
Quality & & \\
Usability & 0,909 & 0,866 \\
User Satisfaction & 0,887 & 0,829 \\
\hline
\end{tabular}

Mengacu dari tabel 7 di atas bisa ditarik kesimpulan jika seluruh konstruknya memenuhi syarat reliabel. Hal tersebut terlihat dari nilainya composite reliability dan cronbach's alpha's yang didapatkan dari perkiraan SmartPLS. Nilai yang dihasilkan ialah $>0,60$ sebagaimana kriteria yang direkomendasikan. Hasil dari Composite Reliability yang dihasilkan > 0,70 yang artinya realibilitas dari indikator dinyatakan baik.

Selanjutnya dilakukan uji Average Variance Extracted (AVE) untuk melakukan pengujian model yang menggambarkan besaran keragaman indikator yang didukung oleh konstruk. Nilai dari AVE $>0,5$ pada tiap indikator dinyatakan memiliki convergent validity yang baik[7].

Tabel 8. Nilai Average Variance Extraced (AVE)

\begin{tabular}{lc}
\hline \multicolumn{1}{c}{ Variabel } & $\boldsymbol{A} \boldsymbol{V E}$ \\
\hline Compensation & 10,755 \\
Contact & 0,830 \\
Fulfillment & 0,660 \\
Information Quality & 0,599 \\
Privacy & 0,644 \\
Service Interaction Quality & 0,672 \\
Usability & 0,713 \\
User Satisfaction & 0,662 \\
\hline
\end{tabular}

Nilai AVE yang ditunjukkan pada tabel 6 menyatakan semua variabel pengujian model memiliki nilai AVE diatas 0,5 sehingga dinyatakan baik dan memenuhi ketentuan pengujian AVE. Uji Discriminant Validity, perhitungan yang berdasarkan pada nilai cross loading dari indikator dan konstruk. Indikator pada pengujian ini dikatakan baik jika kolerasi antara konstruk dan indikator lebih besar dari kolerasi dengan konstruk atau variabel laten yang lain [8]. Hasil pengujian pada tabel 9 menunjukkan nilai cross loading indikator memiliki nilai yang lebih besar dari kolerasi nilai konstruk yang lain. 
Tabel 9. Nilai Cross Loading

\begin{tabular}{|c|c|c|c|c|c|c|c|c|}
\hline & COM & CON & FUL & $I Q$ & $P R I$ & SIQ & $\boldsymbol{U}$ & $U S$ \\
\hline COM1 & 0,868 & 0,631 & 0,439 & 0,487 & 0,495 & 0,470 & 0,353 & 0,428 \\
\hline COM2 & 0,870 & 0,637 & 0,477 & 0,530 & 0,543 & 0,472 & 0,289 & 0,431 \\
\hline CON1 & 0,675 & 0,890 & 0,445 & 0,556 & 0,532 & 0,516 & 0,385 & 0,393 \\
\hline CON2 & 0,673 & 0,925 & 0,496 & 0,616 & 0,568 & 0,518 & 0,450 & 0,468 \\
\hline CON3 & 0,650 & 0,919 & 0,450 & 0,576 & 0,577 & 0,528 & 0,489 & 0,431 \\
\hline FUL1 & 0,515 & 0,453 & 0,853 & 0,586 & 0,480 & 0,564 & 0,331 & 0,580 \\
\hline FUL2 & 0,422 & 0,374 & 0,758 & 0,485 & 0,437 & 0,462 & 0,276 & 0,436 \\
\hline FUL3 & 0,337 & 0,409 & 0,823 & 0,480 & 0,497 & 0,552 & 0,366 & 0,491 \\
\hline IQ1 & 0,416 & 0,447 & 0,510 & 0,760 & 0,497 & 0,508 & 0,364 & 0,391 \\
\hline IQ2 & 0,497 & 0,622 & 0,497 & 0,797 & 0,509 & 0,644 & 0,506 & 0,528 \\
\hline IQ3 & 0,440 & 0,546 & 0,407 & 0,788 & 0,473 & 0,574 & 0,329 & 0,473 \\
\hline IQ4 & 0,508 & 0,558 & 0,501 & 0,702 & 0,469 & 0,585 & 0,463 & 0,539 \\
\hline IQ5 & 0,529 & 0,506 & 0,481 & 0,789 & 0,485 & 0,635 & 0,439 & 0,568 \\
\hline IQ6 & 0,405 & 0,422 & 0,565 & 0,810 & 0,549 & 0,659 & 0,307 & 0,588 \\
\hline IQ7 & 0,371 & 0,381 & 0,497 & 0,766 & 0,444 & 0,631 & 0,350 & 0,577 \\
\hline PRI1 & 0,437 & 0,381 & 0,401 & 0,402 & 0,722 & 0,325 & 0,208 & 0,292 \\
\hline PRI2 & 0,532 & 0,575 & 0,436 & 0,560 & 0,809 & 0,456 & 0,233 & 0,439 \\
\hline PRI3 & 0,467 & 0,502 & 0,514 & 0,499 & 0,839 & 0,491 & 0,299 & 0,424 \\
\hline PRI4 & 0,429 & 0,479 & 0,496 & 0,522 & 0,790 & 0,473 & 0,339 & 0,332 \\
\hline PRI5 & 0,520 & 0,498 & 0,480 & 0,537 & 0,846 & 0,461 & 0,277 & 0,398 \\
\hline SIQ1 & 0,367 & 0,381 & 0,582 & 0,609 & 0,477 & 0,795 & 0,322 & 0,570 \\
\hline SIQ2 & 0,422 & 0,388 & 0,525 & 0,631 & 0,362 & 0,838 & 0,361 & 0,545 \\
\hline SIQ3 & 0,551 & 0,584 & 0,538 & 0,715 & 0,598 & 0,811 & 0,395 & 0,544 \\
\hline SIQ4 & 0,439 & 0,520 & 0,484 & 0,632 & 0,383 & 0,833 & 0,435 & 0,558 \\
\hline U3 & 0,413 & 0,487 & 0,380 & 0,438 & 0,302 & 0,413 & 0,858 & 0,412 \\
\hline U4 & 0,309 & 0,462 & 0,294 & 0,404 & 0,262 & 0,353 & 0,858 & 0,406 \\
\hline U5 & 0,306 & 0,366 & 0,342 & 0,431 & 0,328 & 0,377 & 0,858 & 0,419 \\
\hline U6 & 0,217 & 0,326 & 0,336 & 0,450 & 0,246 & 0,415 & 0,805 & 0,406 \\
\hline US2 & 0,407 & 0,342 & 0,538 & 0,584 & 0,443 & 0,522 & 0,368 & 0,808 \\
\hline US3 & 0,412 & 0,445 & 0,462 & 0,509 & 0,312 & 0,571 & 0,380 & 0,781 \\
\hline US4 & 0,404 & 0,411 & 0,533 & 0,600 & 0,411 & 0,597 & 0,435 & 0,881 \\
\hline US5 & 0,387 & 0,348 & 0,498 & 0,539 & 0,382 & 0,513 & 0,398 & 0,780 \\
\hline
\end{tabular}


Pada tabel 9 menunjukan nilainya cross loading dari setiap indikatornya pada konstruk lebih tinggi blok yang lain. Dapat disimpulkan jika seluruh variabel latennya atau konstruk telah mempunyai nilai discriminant validity yang lebih baik dari blok indikator lainnya.

\section{b. Uji Path Coefficient ( $\beta$ )}

Path coefficient merupakan versi baku menurut bobot regresi linier yang bisa dipakai pada menguji kemungkinan interaksi karena dampak antara variabel statistik pada pendekatan pemodelan persamaan struktural. Bisa diartikan, pengujian path coefficient dicermati menurut nilai ambang batas yaitu 0,1 , dimana koefisien jalur mendeskripsikan dampak kekuatan interaksi antar konstruk. Pada uji coefficient jika nilai ambang batas $>0,1$ jadi bisa disimpulkan path berpengaruh pada model. Berikut merupakan hasil dari pengujian path coefficient.

Tabel 10. Hasil Uji Path Coefficient

\begin{tabular}{lr}
\hline \multicolumn{1}{c}{ Hubungan antar variabel } & $\boldsymbol{\beta}$ \\
\hline Compensation $\rightarrow$ User Satisfaction & 0,106 \\
Contact $\rightarrow$ User Satisfaction & $-0,104$ \\
Fulfillment $\rightarrow$ User Satisfaction & 0,232 \\
Information Quality $\rightarrow$ User & 0,288 \\
Satisfaction & \\
Privacy $\rightarrow$ User Satisfaction & $-0,026$ \\
Service Interaction Quality $\rightarrow$ User & 0,244 \\
Satisfaction & \\
Usability $\rightarrow$ User Satisfaction & 0,154 \\
\hline
\end{tabular}

Hasil dari uji path coefficient pada tabel 10 Menunjukkan bahwa terdapat 2 (dua) jalur yang memiliki nilai dibawah 0,1 yaitu $\mathrm{CON} \rightarrow \mathrm{US}$ yang memiliki nilai $-0,104$, dan $\mathrm{PRI} \rightarrow$ US yang memiliki nilai -0,026 dinyatakan dua jalur tersebut tidak mempunyai signifikansi yang baik didalam modelnya.

c. Uji Coefficient of Derermination $\left(\mathrm{R}^{2}\right)$

Pada penilaian model menggunakan PLS diawali dengan mencermati R-Square pada masing-masing variabel laten terikat. Evaluasi structural model dilakukan menggunakan metode bootstrap dengan melihat nilai coefficient of determination (R-square $\mathrm{R} 2$ ) dari variabel laten endogen dan melihat nilai tstatistic [9]. Berikut adalah hasil dari pengujiannya. Pada prinsipnya dalam penelitian ini memakai 1 buah variabel yang mendapatkan pengaruh dari variabel lain yakni variabel User Satisfaction yang dipengaruhi oleh variabel E-SQual (Fulfillment, Privacy, Compensation dan Contact) dan variabel Webqual 4.0.

Tabel 11. Nilai R Square

\begin{tabular}{lc}
\hline Variabel & $\boldsymbol{R}$ Square \\
\hline User & \\
Satisfaction & 0.574 \\
\hline
\end{tabular}

Tabel 11 memperlihatkan nilai $R$-square variabel user Satisfaction yaitu 0,574. Hasilnya tersebut memperlihatkan jika $57,4 \%$ variabelvariabel E-S-Qual (Fulfillment, Privacy, Compensation dan Contact) dan variabel Webqual 4.0 mempunyai kontribusi dalam kualitas website.

\section{d. Uji Hipotesis}

Hasil uji hipotesis dapat terlihat pada tabel 12, dilakukan dengan menggunakan metode bootstrap. Hasil pengujiannya yang dilaksanakan melalui bootstrapping dari analisa PLS ialah variabel Fulfillment, Information Quality, 
Service Interaction Quality dan Usability tidak berpengaruh signifikan terhadap variabel User Satisfaction hal tersebut disebabkan nilai $p$-value $<0,005$, sedangkan variabel Compensation, Contact dan Privacy tidak berpengaruh signifikan terhadap variabel User Satisfaction hal ini dikarenakan nilai $p$-value lebih besar dari 0,005 .
Tabel 13 merupakan rangkuman hasil pengujian hipotesis yaitu terdapat empat hipotesis diterima dan tiga hipotesis yang ditolak. Empat faktor yang mempengaruhi tingkat kualitas website kitabisa.com diantaranya satu varibel dari metode e-s-qual yaitu fulfillment, dan terdapat 3 variabel dari metode webqual 4.0 yaitu usability, information quality, dan service interaction quality.

Tabel 12 Hasil Uji Hipotesis

\begin{tabular}{lccccc}
\hline & $\begin{array}{c}\text { Original } \\
\text { Sample } \\
(\boldsymbol{O})\end{array}$ & $\begin{array}{c}\text { Sample } \\
\text { Mean } \\
(\boldsymbol{M})\end{array}$ & $\begin{array}{c}\text { Standard } \\
\text { Deviation } \\
(\text { STDEV })\end{array}$ & $\begin{array}{c}\text { T Statistics } \\
(\mid \text { O/STDEV|) }\end{array}$ & $\begin{array}{c}\boldsymbol{P} \\
\text { Values }\end{array}$ \\
\hline $\begin{array}{l}\text { Compensation } \rightarrow \text { User } \\
\text { Satisfaction }\end{array}$ & 0,106 & 0,105 & 0,078 & 1,354 & 0,176 \\
$\begin{array}{l}\text { Contact } \rightarrow \text { User } \\
\text { Satisfaction }\end{array}$ & $-0,104$ & $-0,103$ & 0,081 & 1,291 & 0,197 \\
$\begin{array}{l}\text { Fulfillment } \rightarrow \text { User } \\
\text { Satisfaction }\end{array}$ & 0,232 & 0,224 & 0,071 & 3,267 & 0,001 \\
$\begin{array}{l}\text { Information Quality } \\
\rightarrow \text { User Satisfaction }\end{array}$ & 0,288 & 0,284 & 0,095 & 3,029 & 0,003 \\
$\begin{array}{l}\text { Privacy } \rightarrow \text { User } \\
\text { Satisfaction } \\
\text { Service Interaction }\end{array}$ & $-0,026$ & $-0,018$ & 0,073 & 0,359 & 0,719 \\
$\begin{array}{l}\text { Quality } \rightarrow \\
->\text { User Satisfaction }\end{array}$ & 0,244 & 0,248 & 0,086 & 2,849 & 0,005 \\
$\begin{array}{l}\text { Usability } \rightarrow \text { User } \\
\text { Satisfaction }\end{array}$ & 0,154 & 0,153 & 0,065 & 2,374 & 0,018 \\
\hline
\end{tabular}

Tabel 13. Rangkuman Hasil Pengujian Hipotesis

\begin{tabular}{clccc}
\hline No & \multicolumn{1}{c}{ Keterangan } & $\begin{array}{c}\text { Nilai } \\
\text { Koefisien } \\
\text { Jalur }\end{array}$ & $\begin{array}{c}\text { Nilai } \\
\text { p-value }\end{array}$ & $\begin{array}{c}\text { Hasil } \\
\text { Pengujian }\end{array}$ \\
\hline $1 \quad \begin{array}{l}\text { Fulfillment } \rightarrow \text { User Satisfaction } \\
\text { Terdapat pengaruh yang } \\
\text { siginifikan dan positif diantara } \\
\text { Fulfillment pada Tingkat } \\
\text { Kualitas Website Kitabisa.com } \\
2 \quad\end{array}$ & 0,106 & 0,176 & Diterima \\
& $\begin{array}{l}\text { Privacy } \rightarrow \text { User Satisfaction } \\
\text { Terdapat pengaruh yang } \\
\text { siginifikan dan positif diantara } \\
\end{array}$ & & & \\
Privacy pada Tingkat Kualitas & $-0,104$ & 0,197 & Ditolak \\
& Website Kitabisa.com & & &
\end{tabular}




\begin{tabular}{|c|c|c|c|c|}
\hline No & Keterangan & $\begin{array}{c}\text { Nilai } \\
\text { Koefisien } \\
\text { Jalur }\end{array}$ & $\begin{array}{c}\text { Nilai } \\
\text { p-value }\end{array}$ & $\begin{array}{c}\text { Hasil } \\
\text { Pengujian }\end{array}$ \\
\hline 3 & $\begin{array}{l}\text { Compensation } \rightarrow \text { User } \\
\text { Satisfaction } \\
\text { Terdapat pengaruh yang } \\
\text { siginifikan dan positif diantara } \\
\text { Compensation pada Tingkat } \\
\text { Kualitas Website Kitabisa.com }\end{array}$ & 0,232 & 0,001 & Ditolak \\
\hline 4 & $\begin{array}{l}\text { Contact } \rightarrow \text { User Satisfaction } \\
\text { Terdapat pengaruh yang } \\
\text { siginifikan dan positif diantara } \\
\text { Contact pada Tingkat Kualitas } \\
\text { Website Kitabisa.com }\end{array}$ & 0,288 & 0,003 & Ditolak \\
\hline 5 & $\begin{array}{l}\text { Usability } \rightarrow \text { User Satisfaction } \\
\text { Terdapat pengaruh yang } \\
\text { siginifikan dan positif diantara } \\
\text { Usability pada Tingkat } \\
\text { Kualitas Website Kitabisa.com }\end{array}$ & $-0,026$ & 0,719 & Diterima \\
\hline 6 & $\begin{array}{l}\text { Information Quality } \rightarrow \text { User } \\
\text { Satisfaction } \\
\text { Terdapat pengaruh yang } \\
\text { siginifikan dan positif diantara } \\
\text { Information Quality pada } \\
\text { Tingkat Kualitas Website } \\
\text { Kitabisa.com }\end{array}$ & 0,244 & 0,005 & Diterima \\
\hline 7 & $\begin{array}{l}\text { Service Interaction Quality } \\
\rightarrow \text { User Satisfaction } \\
\text { Terdapat pengaruh yang } \\
\text { siginifikan dan positif diantara } \\
\text { Service Interaction Quality } \\
\text { pada Tingkat Kualitas Website } \\
\text { Kitabisa.com }\end{array}$ & 0,154 & 0,018 & Diterima \\
\hline
\end{tabular}

Setelah melakukan beberapa uji menggunakan SmartPLS 3.0 diperoleh hasil akhir model akhir penelitian yang dapat dilihat pada gambar 2. Terdapat 3 (tiga) variabel yaitu privacy, compensation, dan contact yang memiliki nilai $\mathrm{p}$-value yang lebih besar dari lebih besar dari 0,05 atau tidak memiliki pengaruh signifikan dan positif dengan tingkat kualitas tingkat kualitas website kitabisa.com.

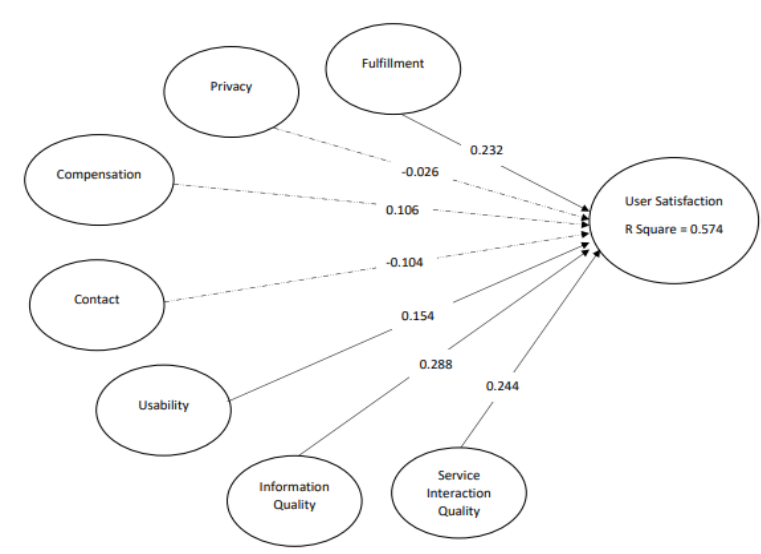

Gambar 2. Model Akhir Penelitian 
Keterangan :

$-\cdots-\cdots-\cdots$ Nilai p-value lebih besar sehingga tidak ada pengaruh yang signifikan dan positif sehingga Hipotesis Ditolak.

Hasil survey oleh 203 responden mendapatkan kolerasi $R$-square sebesar 0.574 menunjukkan nilai $R$-square untuk variabel User Satisfaction diperoleh sebesar 0,574. Hasil ini menunjukkan bahwa 57,4\% variabel variabel E-S-Qual (Fulfillment, Privacy, Compensation dan Contact) dan variabel Webqual 4.0 (Usability, Information Quality dan Service Interaction Quality) mempunyai kontribusi dalam kualitas website.
Hasil dari survey kuesioner yang telah disebarkan melalui google form menunjukan bahwa kualitas website kitabisa.com memiliki kualitas yang baik berdasarkan nilai loading factor pada beberapa aspek yaitu kecepatan dan ketepatan website dalam mencari halaman yang diinginkan pengguna, keamanan website, kompensasi website saat ada masalah, website up to date, dan layanan customer service. Namun ada aspek yang dimana mempunyai loading factor yang rendah yang harus diperhatikan dan dilakukan perbaikan yang dapat dilihat pada Tabel 14.

Tabel 14 Rekomendasi Perbaikan

\begin{tabular}{|c|c|c|c|c|}
\hline No & Aspek & Dimensi & Tindakan & Rekomendasi \\
\hline 1 & \begin{tabular}{l}
\multicolumn{3}{l}{ FUL2: Informasi donasi yang } \\
Disajikan pada website \\
Kitabisa.com \\
bersifat jujur
\end{tabular} & E-S-Qual & $\begin{array}{ll}\text { Update } & \text { dan } \\
\text { modifikasi } & \end{array}$ & $\begin{array}{l}\text { Menambahkan } \\
\text { penggalang dana serta informasi } \\
\text { tujuan dari penggalangan dana }\end{array}$ \\
\hline 2 & $\begin{array}{l}\text { PRI1: Kitabisa.com melindungi } \\
\text { data personal pengguna }\end{array}$ & & Upgrade & $\begin{array}{l}\text { Melakukan pengembangan terkait } \\
\text { keamanan system }\end{array}$ \\
\hline 3 & $\begin{array}{l}\text { PRI2: Kitabisa.com aman dari } \\
\text { serangan keamanan informasi }\end{array}$ & & Upgrade & $\begin{array}{l}\text { Melakukan pengembangan terkait } \\
\text { keamanan system }\end{array}$ \\
\hline 4 & $\begin{array}{l}\text { COM1: Pengguna dapat } \\
\text { melakukan proses refund dana } \\
\text { saat terjadi masalah saat } \\
\text { berdonasi }\end{array}$ & & Modifikasi & Aplikasi Re-fund \\
\hline 5 & $\begin{array}{l}\text { COM2: Kitabisa.com } \\
\text { menyediakan customer service } \\
\text { yang responsible }\end{array}$ & & Modifikasi & Aplikasi chat box via whatsapp \\
\hline 6 & $\begin{array}{l}\text { CON1: Kitabisa.com } \\
\text { menyediakan call center dan live } \\
\text { chat yang dapat mengatasi } \\
\text { masalah pengguna }\end{array}$ & & Modifikasi & Aplikasi Live Chat \\
\hline 7 & $\begin{array}{ll}\text { U2: } & \text { Tampilan } \\
\text { kitabisa.com menarik }\end{array}$ & $\begin{array}{l}\text { Webqual } \\
4.0\end{array}$ & $\begin{array}{l}\text { Update } \\
\text { modifikasi }\end{array}$ & $\begin{array}{lll}\text { Pengembangan } & \text { tampilan } & \text { UI/UX } \\
\text { yang lebih baik } & & \end{array}$ \\
\hline 8 & $\begin{array}{l}\text { IQ3: Kitabisa.com menampilkan } \\
\text { informasi yang relevan }\end{array}$ & & Update & Update berkala \\
\hline 9 & $\begin{array}{l}\text { US1: Saya suka dengan tampilan } \\
\text { website Kitabisa.com }\end{array}$ & $\begin{array}{l}\text { User } \\
\text { Satisfaction }\end{array}$ & $\begin{array}{l}\text { Update } \\
\text { modifikasi }\end{array}$ & $\begin{array}{lll}\text { Pengembangan } & \text { tampilan } & \text { UI/UX } \\
\text { yang lebih baik } & & \end{array}$ \\
\hline 10 & $\begin{array}{l}\text { US6: Setiap hari saya mengakses } \\
\text { website kitabisa.com }\end{array}$ & & $\begin{array}{l}\text { Update, upgrade, } \\
\text { dan modifikasi }\end{array}$ & $\begin{array}{l}\text { Design website yang ramah dan } \\
\text { menarik, iklan dan promosi untuk } \\
\text { menarik pengguna. }\end{array}$ \\
\hline
\end{tabular}


Berdasarkan tabel 14 variabel yang memiliki angka loading factor yang rendah diantaranya fulfillment, privacy, compensation, contact, information quality, user satisfaction memerlukan rekomendasi untuk update, upgrade atau modifikasi. Hal ini dikuatkan dengan hasil penelitian sebelumnya (Andiputra dan tanamal, 2020) melakukan analisis usability dengan metode Webuse pada Website Kitabisa.com variabel desain tampilan website memiliki skor yang kurang baik yang artinya tampilan website masih kurang menarik dan kurang dapat memuaskan pengguna [10]. Aspek tersebut sangat mempengaruhi kualitas website dan kepuasaan pengguna kitabisa.com dalam menggunakan website. Rekomendasi ini diharapkan dapat menjadi salah satu pendukung keputusan bagi Kitabisa.com dalam meningkatkan kualitas website.

\section{KESIMPULAN}

Dari tujuh hipotesis yang diajukan dalam mempengaruhi kepuasan pengguna, ada tiga hipotesis yang ditolak berdasarkan hasil pengujian path coefficient, yaitu hipotesis Compensation yang mempengaruhi Kepuasan Pengguna (COM $\rightarrow \mathrm{US})$, hipotesis Contact yang mempengaruhi kepuasan pengguna $(\mathrm{CON} \rightarrow \mathrm{US}$ ), hipotesis Privacy yang mempengaruhi user satisfaction (PRI $\rightarrow \mathrm{US})$.

Ditolaknya Compensation, Contact, dan Privacy pada hipotesis penelitian ini berbeda dengan penelitian-penelitian sebelumnya compensation, contact, dan privacy berpengaruh terhadap kualitas website. Hal ini menunjukkan bahwa faktor-faktor pada website kitabisa.com yang lebih mempengaruhi kepuasan pengguna adalah kecepatan dan ketepatan website dala mencari halaman yang diinginkan pengguna, keamanan website, kompensasi website saat ada masalah, website up to date, dan layanan customer service.

User satification atau kepuasaan pengguna memiliki pengaruh terhadap kualitas website hal ini terbukti dari nilai r-square 0,574 . Hasil ini menunjukkan bahwa $57,4 \%$ variabel - variabel E-S-Qual (Fulfillment, Privacy, Compensation dan Contact) dan variabel Webqual 4.0 (Usability, Information Quality dan Service Interaction Quality) mempunyai kontribusi dalam kualitas website.

Untuk melakukan perbaikan tingkat kualitas website, kitabisa.com dapat meningkatkan pada aspek tampilan website kitabisa.com dan kesenangan pengguna dalam menggunakan website. Peningkatan tampilan website dapat menarik pengguna, kesenangan pengguna dan dapat meningkatkan kualitas website. Untuk penelitian selanjutnya dengan topik ssejenis dengan penelitian ini diharapkan dapat menambah variabel dan menggabungkan metode lain yang mempunyai peluang mempengaruhi tingkat kualitas website.

Penambahan jumlah responden yang lebih banyak dan cakupan responden yang lebih luas pada penelitian berikutnya agar data yang dihasilkan dan di uji memilki hasil yang variatif dan dapat di eksplor lebih jauh terhadap tingkat kualitas website kitabisa.com dalam mempengaruhi kepuasan pengguna. 


\section{DAFTAR PUSTAKA}

[1] Wicks, M., Crowdfunding-an introduction. Victoria: Blue Beetle Books. 2013

[2] Pratama, Y., \& Kusumo, D. S. Pengukuran Kualitas Website CDC Universitas Telkom Menggunakan Metode Webqual 4.0. eProceedings of Engineering, 2(1), 2015.

[3] Warjiyono, W., \& Hellyana, C. M., Pengukuran Kualitas Website Pemerintah Desa Jagalempeni Menggunakan Metode Webqual 4.0. Jurnal Teknologi Informasi Dan Ilmu Komputer, 5(2), 139., 2018.

[4] Hartono, Jogiyanto., Metode Penelitian Bisnis. Edisi Ke-6. Yogyakarta. Universitas Gadjah Mada. 2014.

[5] Ahlan, A. R., Kartiwi, M., \& Sukmana, H. T., Measurement of information system project success based on perceptions of the internal stakeholders., 2015.

[6] Ghozali, I., Structural Equation Modeling: Metode Alternatif Dengan Partial Least Square (pls). Badan Penerbit Universitas Diponegoro., 2008.

[7] Hair Jr, J. F., Hult, G. T. M., Ringle, C., \& Sarstedt, M. A primer on partial least squares structural equation modeling (PLSSEM). Sage publications., 2016.

[8] Sarstedt, M., Ringle, C. M., \& Hair, J. F., Partial least squares structural equation modeling. Handbook of market research, 26(1), 1-40., 2017.

[9] Seta, H. B., Hidayanto, A. N., \& Abidin, Z., Variables Affecting E-learning Services Quality in Indonesian Higher Education: Students' Perspectives. Journal of Information Technology Education, 19. 2020.

[10] Andiputra, K., \& Tanamal, R.. Analisis Usability Menggunakan Metode Webuse pada Website kitabisa.com., 2020. 